\title{
La Balouta exhumed karst: a Roman gold-mine-derived landscape within the Las Médulas UNESCO World Heritage Site (Spain)
}

\author{
José M. Redondo-Vega ${ }^{1}$, Eduardo Alonso-Herrero² ${ }^{2}$ Javier Santos-González ${ }^{1 *}$, \\ Rosa B. González-Gutiérrez ${ }^{1}$, and Amelia Gómez-Villar ${ }^{1}$
}

${ }^{1}$ Geography and Geology Department, University of León. Campus de Vegazana, s/n. 24007, LEÓN, Spain

${ }^{2}$ Engineering and Agricultural Sciences Department, University of León. Avda. Portugal, 41. 24007, LEÓN, Spain

\begin{abstract}
The La Balouta Valley, located in the extreme SW region of the Las Médulas Natural Monument and UNESCO World Heritage Site (León, Spain), is one of the largest gold-mining sites developed by the Romans more than 2,000 years ago when excavating a thick series of red Miocene sediments in the area. The main determining feature of the La Balouta Valley, especially if we compare it with the Sil River Valley of which it is a tributary, is its status of a non-functional valley. It is a dry paleo-valley with a flat bottom and is characterized by limited surface water runoff and the presence of small cavities, channels, and residual karst topography. Variscan structures that form the structural framework of the study area underwent long-term erosion and supported deep sediment accumulation in the area during the Miocene, reaching depths of more than $100 \mathrm{~m}$. A portion of these sediments accumulated over a karst, as indicated by karst channels that exhibit total and locally partial filling with red sediments similar to those mined at Las Médulas roughly $2 \mathrm{~km}$ further to the east. The presence of gold particles in one of the sediment samples and the identification of several characteristics common of formations mined by the Romans lead us to deem the La Balouta Valley an ancient paleokarst that was initially fossilized by deposition of red Miocene sediments and subsequently excavated via historical mining activities, which formed its current characteristics. In La Balouta, natural and anthropogenic processes have produced a unique cultural landscape that is reflective of systematic gold mining of sediments on the NW Iberian Peninsula by the Romans.
\end{abstract}

Keywords: $\quad$ exhumed karst; Roman gold mines; paleokarst landforms; world heritage site; Las Médulas Received 10 April 2015; Revised 23 June 2015; Accepted 26 June 2015

Citation: Redondo-Vega J.M., Alonso-Herrero E., Santos-González J., González-Gutiérrez R.B. and Gómez-Villar A., 2014. La Balouta exhumed karst: a Roman gold-mine-derived landscape within the Las Médulas UNESCO World Heritage Site (Spain). International Journal of Speleology, 44 (3), 267 - 276. Tampa, FL (USA) ISSN 0392-6672 http://dx.doi.org/10.5038/1827-806X.44.3.5

\section{INTRODUCTION}

This study examines a paleokarst exhumed as a result of mining operations conducted by the Ancient Romans in the recovery of gold contained in Cenozoic sediment that previously covered the ancient karstic formations. Paleokarsts-related sedimentary deposits containing valuable mineral substances such as iron ores, bauxite, lead ores, precious stone deposits (Bosák, 1989) or gold (i.e., in the Urals (Filippov, 2006)) have been mined in many parts of the world. Known cases in the Iberian Peninsula have also shown that ancient mining operations coincided with areas of ancient karstification. For example, the Romans mined iron in Cerro del Hierro (Miras Ruiz \& Galán
Huertos, 1992) and Peña Cabarga (Fernández Ochoa \& Morillo Cerdán, 2013).

However, this phenomenon had not been examined with reference to gold mining. In 2009, the inventory of Geological Heritage Sites of the Province of Palencia (Fernández-Martínez et al., 2009) was published. The inventory described a karst that was exhumed via mining activities due to its value as a geological and mining heritage resource (Redondo Vega et al., 2010). It is known as the Los Peñucos karst and is located in the Cantabrian Mountains range close to the village of Camporredondo de Alba $(175 \mathrm{~km}$ to the NE of La Balouta). It is a small outcropping of Paleozoic limestone with isolated dissolution forms lying on the shore of the Camporredondo reservoir (in 
fact, the lower portion of the karst is hidden below the reservoir's high-water mark, as the karst lies nearly at the base of the valley floor). Here, a complex karstic topography that Roman miners uncovered while extracting gold and removing waste material is found. The coarse fraction of the mining debris now forms accumulations around the exhumed karst in volumes and locations that, far from being related to natural processes, reflect an anthropogenic origin.

In contrast, the exhumed karst (Stevanovic, 2015) considered in this paper is located at the top of the La Balouta Valley (Fig. 1) (Universal Transverse Mercator, Zone 29, Northern Hemisphere, X 68215 , Y 470240 - IGN, 2008) and E-SE of the Las Médulas UNESCO World Heritage Site (UNESCO, 2015), which contains one of the largest Ancient Roman gold mining operation sites (Bird, 1984; Keay, 1988). The study area covers a "Y"-shaped flat-bottomed valley, $1.5 \mathrm{~km}$ in length that has formed with in Paleozoic limestone. Abundant mining debris (known locally as murias, Sánchez-Palencia et al., 1999) and numerous karstic channels -some that are sealed by red Miocene conglomerates and others that are only partially or fully excavated (Fig. 2) - are its main features, although dense vegetation has commonly prevented its direct observation. Thus, artefacts of Roman gold-mining activities and the presence of karstified limestone form characteristic features of the valley.

Currently, La Balouta is not a functional valley, as indicated by an absence of concentrated water runoff on its flat floor (Fig. 3) and by a succession of terraces and fences that cross it transversally. These features characterize the formation as a paleo-valley, and especially if we compare it with the steep gorge carved by the Sil River located immediately to the west, where the La Balouta Valley converges.

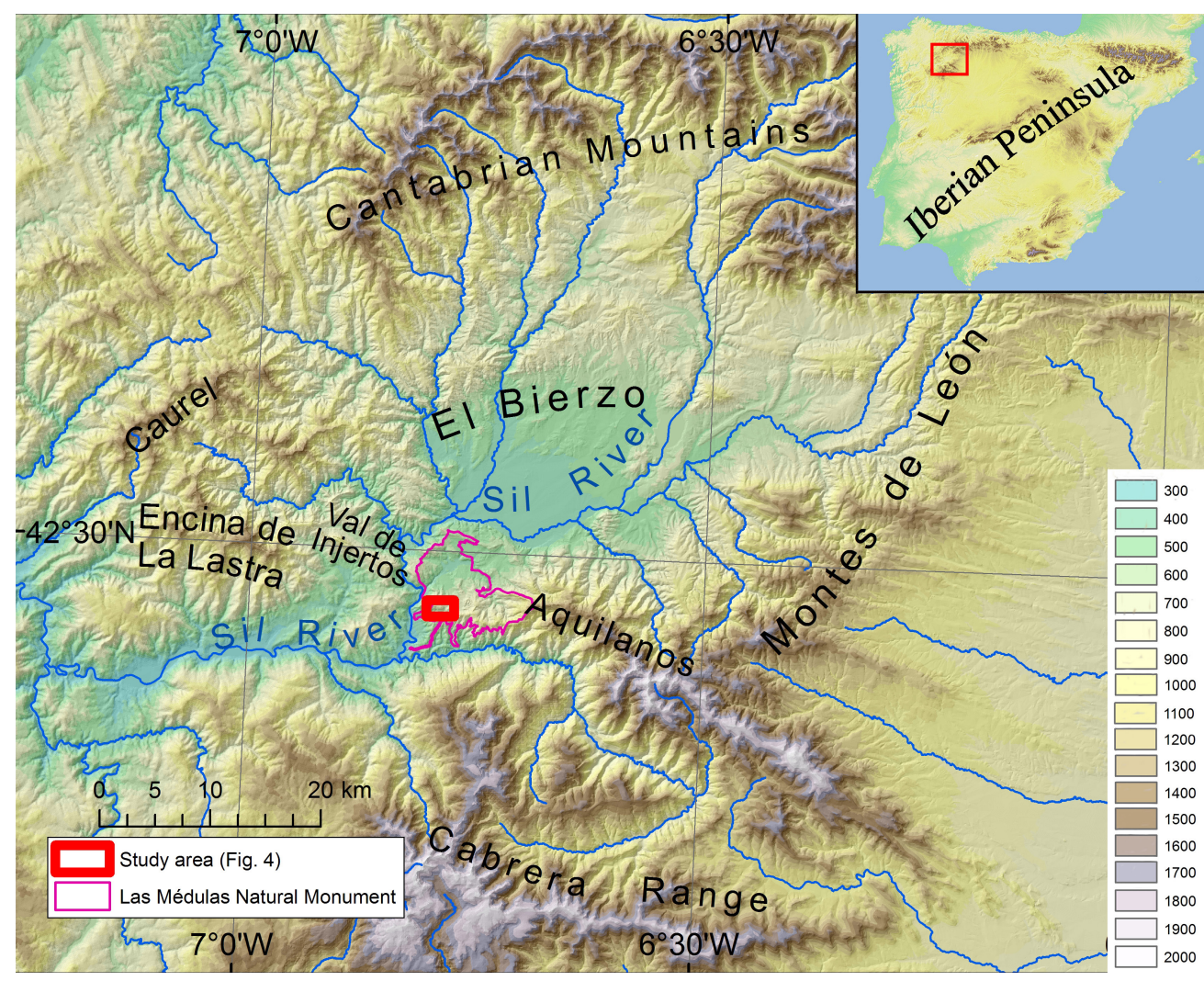

Fig. 1. Location of the study area.

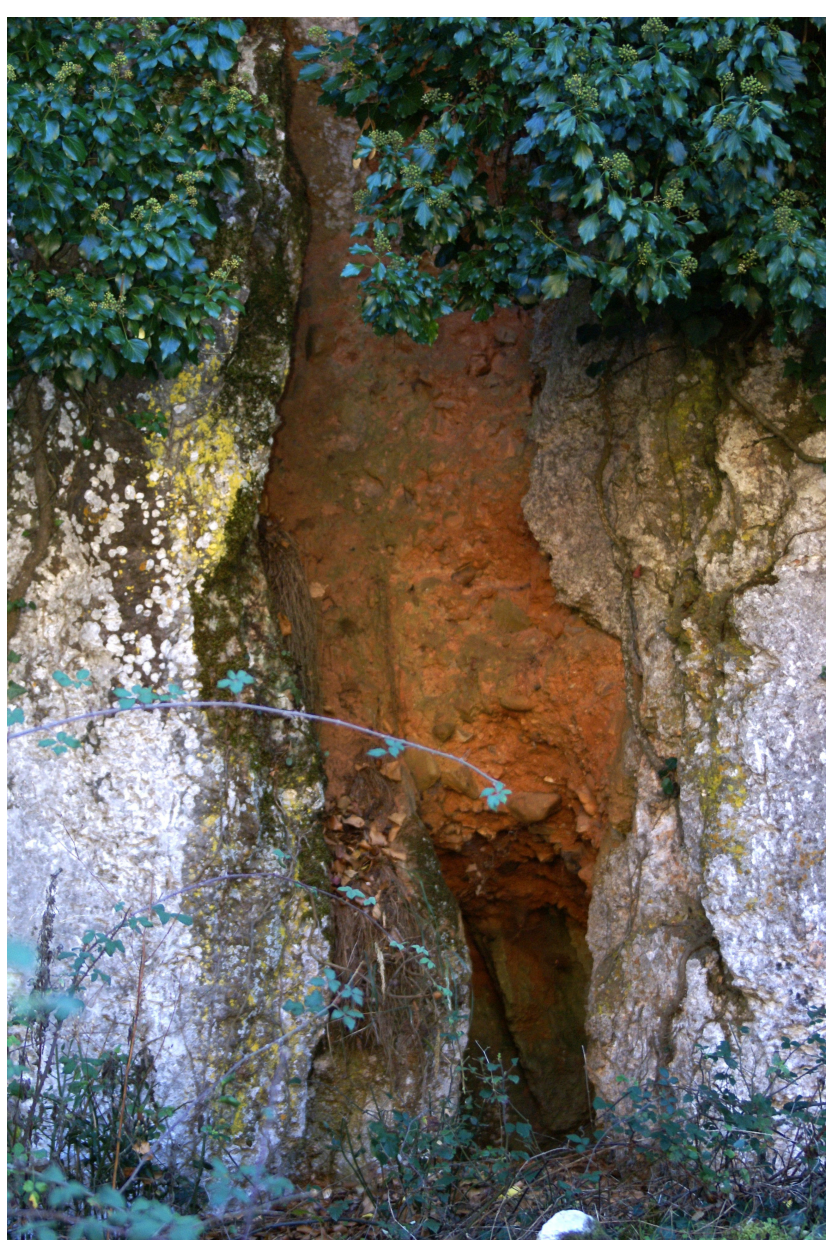

Fig. 2. Vertical channel of the ancient paleokarst, which was almost completely excavated but which conserves Miocene conglomerate components in its upper section.

Given that thousands of people visit Las Médulas every year and given the valley's triple status as a Natural Monument, Archaeological Site, and World Heritage Site, it is surprising that this valley has not been examined until now. Its somewhat marginal location in relation to the center of the visited area may contribute to this lack of attention.

Whereas a number of studies have examined gold mining operations in Las Médulas, the La Balouta Valley has been viewed as a marginal area of the great Roman mine, where no gold was extracted. Thus, Hérail (1984) considers it a valley with steep cliff boundaries that is filled with mining waste materials but that lies outside of the main operation. Other authors such as Domergue (1987) cite small mining operations east of the unpopulated center of La Balouta, where five narrow runoff drainage channels of the Las Médulas 


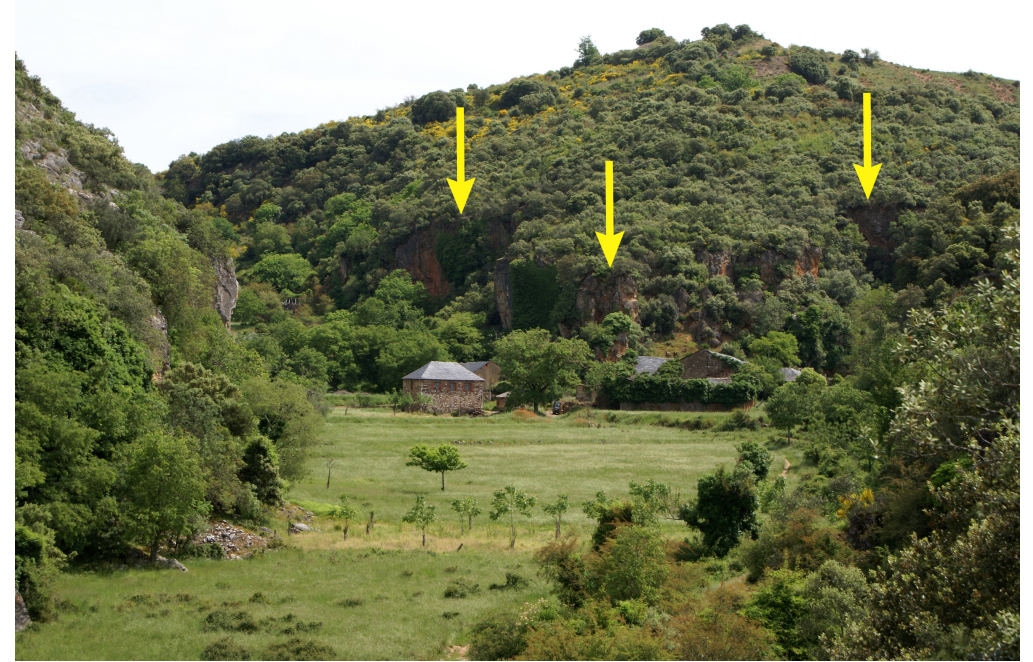

Fig. 3. La Balouta, the arrows highlight one section of karst that was exhumed by Roman gold mining. faulted Paleozoic limestone block of the La Aquiana Formation (Abril Hurtado et al., 1982). The end of the limestone outcrop gives way to black Ordovician slates (Abril Hurtado et al., 1982), which crop out in a small section of the valley. As expected, this section is the only one that does not present paleokarst remnants, though it does include remains of ancient mining excavations (Fig. 4).

East of the site, limestone and slate form the basement for a thick sequence of red Cenozoic sediments of the Santalla and Las Médulas formations (Hérail, 1984). These formations, especially the Santalla Formation, were discovered and mined by Roman miners for their gold content. Remnants of these sediments are still visible today, filling cracks and channels in the limestone of the area.

mine converge, though they are not recognized as part of the main valley and/or represented on maps. Sánchez-Palencia et al. (1999) place the La Balouta Valley clearly outside of the area mined at Las Médulas, though they recognize it as a "tailing fan" of the main mine or as a site of accumulated waste material generated from the mine (Pérez García \& Sánchez-Palencia, 2000).

Studies of karstification phenomena in this area are scarce. The earliest investigations were conducted in the mid-19 ${ }^{\text {th }}$ century by a romantic writer who visited a cave in the pass towards La Balouta and who noted the presence of stalactites, mosses, and other petrified plants (Gil \& Carrasco, 1985). The author spoke, unknowingly, of two karstic processes: namely,

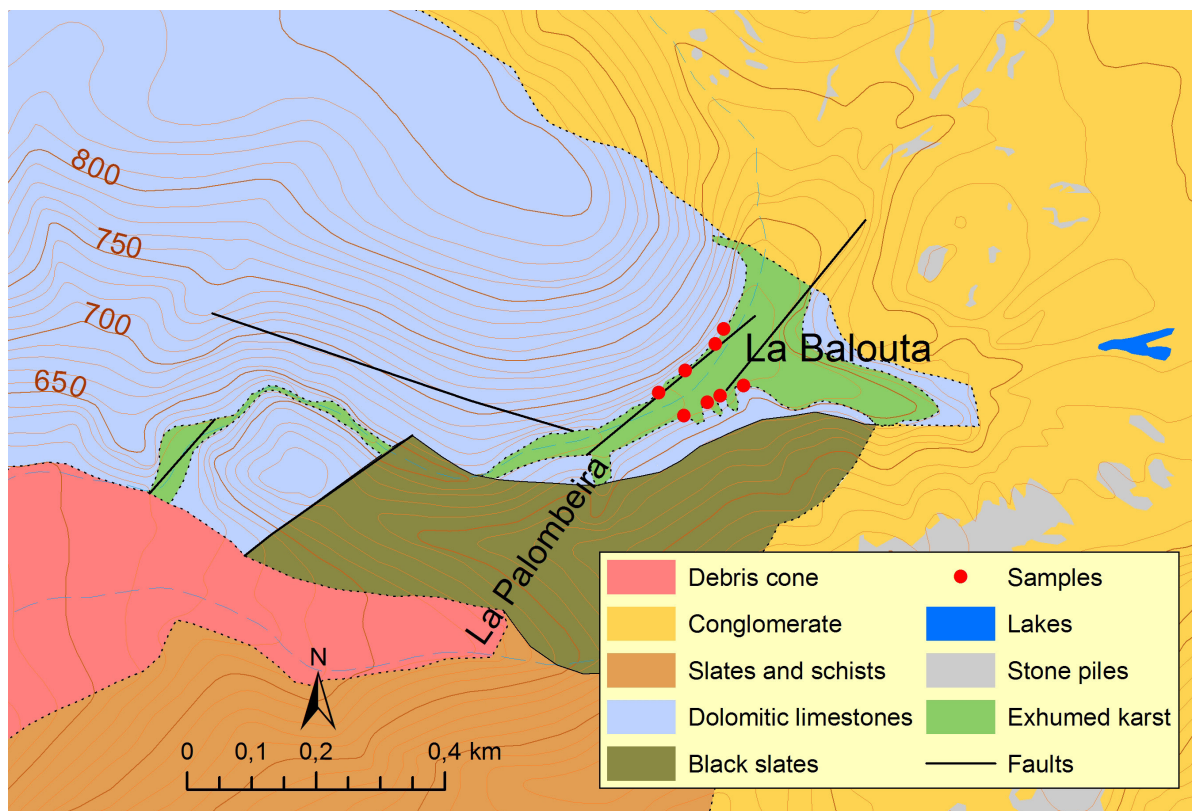

Fig. 4. Geological outline of the La Balouta Valley. See location on Fig.1. Modified from Abril Hurtado et al. (1982). speleothems and the formation of calcareous tuffs. The identification of karstified limestone filled with basal conglomerates from the Las Médulas Tertiary located $1.5 \mathrm{~km} \mathrm{NW}$ of La Balouta (Abril Hurtado et al., 1978) and of karstic landforms in the neighboring Sierra de la Encina de la Lastra (Redondo Vega et al., 2004) has been much more recent. Finally, Martín-González \& Heredia (2010) examined the paleokarst of the La Aquiana Formation limestone, which exhibits vertical cavities filled with coarsegrained Tertiary deposits.

\section{GEOLOGICAL SETTING}

The La Balouta Valley is positioned between the large gold mining operation at Las Médulas and a gorge that the Sil River has formed on the far eastern side of the calcareous mountain block of the Sierra de la Encina de la Lastra. The study area corresponds with the upper reaches of the valley (surrounding an abandoned village of the same name), which was excavated along the far end of the fractured and

The La Balouta Valley is a karstic dry valley (karstic dry valley, Jennings, 1987; 2003; dry valley, Stevanovic, 2015; vallées sèches, Salomon, 2000). An absence of runoff in the valley, even after periods of strong precipitation, suggests the presence of subterranean water circulation and intense limestone karstification, as demonstrated by channels of this type located on both sides of the valley. In fact, the inhabited area of the valley was abandoned during the 1970s due to limited water reserves in the valley, forcing inhabitants to obtain water from the village of Las Médulas located $2 \mathrm{~km}$ away. An absence of water circulation at the bottom of the valley is also suggested by the nature of traditional agricultural activities in the area, with parcels occupying the entire valley floor and with farm fences oriented transversely from one side of the valley to the other.

The valley axis follows the main structural orientations of the area: NE-SW and NW-SE. Abrupt right-angle changes in the valley denote the valley's adaptation to lines of weakness in the geological structure and to fractures and faults that have influenced karstification and valley development. 


\section{METHODS}

Black and white aerial photographs from 1956 (Ejército del Aire, 1956) and more-recent color orthophotographs (IGN, 2008) were analyzed. These photos reveal significant changes in land use and vegetation density patterns. More specifically, the expansion of forest cover has hidden several morphological features that were previously visible. Comparative analyses of old and recent aerial photographs were conducted to form an evolutionary outline for the La Balouta Valley and to locate some major karstified outcrops and spreads of mining waste materials. This analysis also verified the relationship between this initially marginal gold deposit area and the rest of the Roman gold-mining operation at Las Médulas located further east of the study area.

Following initial outlines obtained via aerial photography analyses, fieldwork was conducted: the specific locations of exhumed paleokarst remnants and the verification of mining activities in karstified areas of the La Balouta Valley.

Moreover, using a 1:50,000-scale geological map (Abril Hurtado et al., 1982), a detailed geological outline of the valley was developed based on observations of calcareous outcrops, Paleozoic basement materials (Ordovician limestone and slates), and Cenozoic conglomerate cover features. Our fieldwork results verified findings of previous studies of aerial photographs and corrected certain characteristics that were difficult to interpret due to dense vegetation cover present in the area.

When conducting fieldwork, sediment samples were gathered (four samples in 2011) from semiexcavated karstic channels of the La Balouta Valley to check for the presence of gold. After favorable results were obtained for the first sample gathered (Fig. 5), additional sediment samples were collected (four samples in December 2013) from several karstic channels on both sides of the valley that had been partially excavated by the Romans. The obtained samples were examined in a laboratory setting, and finer materials of the conglomerate matrix (USDA classification) and the granulometry of sand-sized material were classified. The objective of these analyses was to identify Cenozoic sediment formations responsible for karst fossilization, as only the Santalla Formation and, to a lesser degree, the Las Médulas Formation contain significant traces of gold (SánchezPalencia et al., 1999).

\section{RESULTS}

\section{Granulometric analysis}

Sediments that covered and buried the karst and that filled cavities of the La Balouta karstic complex are polymictic paraconglomerates with a sandy-clayloam and sandy-loam matrix (USDA texture, Fig. 6 and Table 1). The proportions of coarse elements found, from gravel to pebbles, were quite variable, ranging from $30 \%$ to $80 \%$. Angular vein-quartz pebbles and gravel were abundant, and well-rounded quartzite pebbles and gravel, sandstone and metamorphic slate

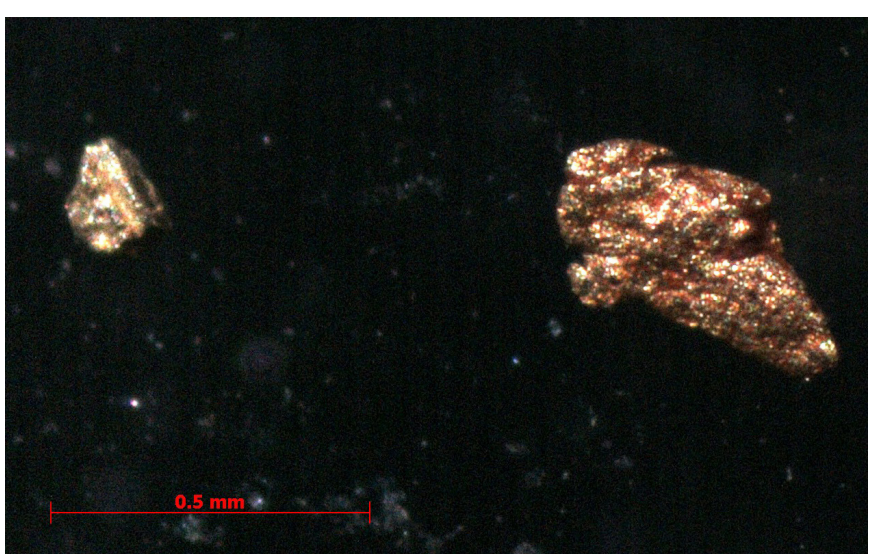

Fig. 5. Gold nuggets obtained from one of the samples gathered from the La Balouta Valley.

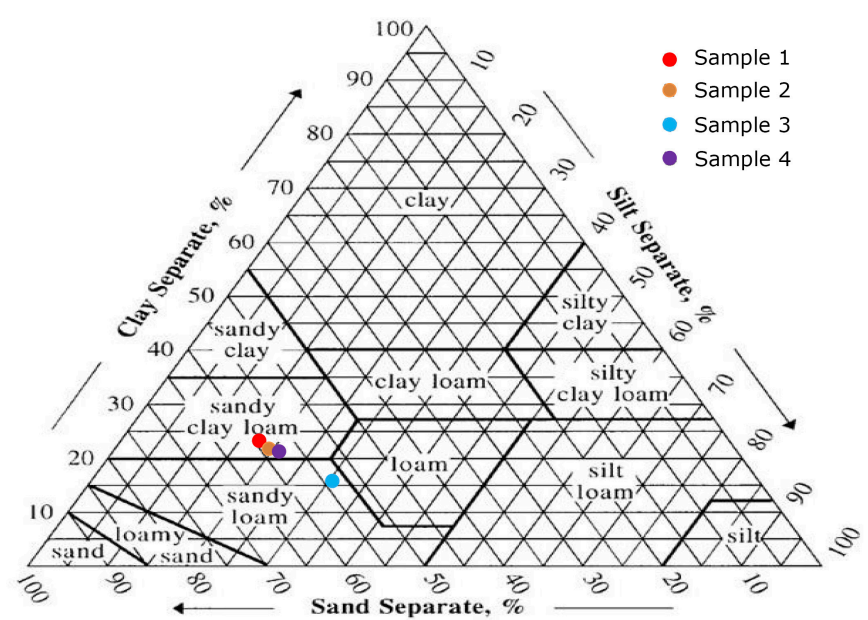

Fig. 6. Soil texture classification of the samples using the USDA soil texture classification system. Triangular diagram available on-line at http://www.usda.gov

Table 1. Percentage of sand, silt, and clay in the samples gathered in La Balouta.

\begin{tabular}{|l|c|c|c|}
\hline \multicolumn{1}{|c|}{ Sample } & Sand & Silt & Clay \\
\hline 1a & 59.3 & 23.0 & 17.7 \\
\hline 1b & 59.3 & 23.0 & 17.7 \\
\hline 1 (average) & 59.3 & 23.0 & 17.7 \\
\hline 2a & 58.3 & 21.0 & 20.7 \\
\hline 2b & 59.3 & 22.0 & 18.7 \\
\hline 2 (average) & 58.8 & 21.5 & 19.7 \\
\hline 3a & 54.3 & 15.0 & 30.7 \\
\hline 3b & 53.3 & 16.0 & 30.7 \\
\hline 3 (average) & 53.8 & 15.5 & 30.7 \\
\hline 4a & 57.3 & 22.0 & 20.7 \\
\hline $4 b$ & 58.3 & 20.0 & 21.7 \\
\hline 4 (average) & 57.8 & 21.0 & 21.2 \\
\hline
\end{tabular}

samples were also found. The matrix is of a yellowish red color 5YR5/6(d)-5YR4/6(h), mainly due to the presence of clay that is colored with iron sesquioxides.

The sandy fraction (2 $\mathrm{mm}-0.05 \mathrm{~mm})$ (USDA), which is the most abundant among the fine materials (from 53\% to 59\%), exhibits a relatively homogeneous distribution by size: very coarse sand $24.8 \%$, coarse sand $17.1 \%$, medium sand $23.1 \%$, fine sand $20.8 \%$, and very fine sand $14.2 \%$.

Paraconglomerates located in the outer portion of the studied cavities were cleaned and found to contain small traces of carbonate. However, those located towards the channel interior presented high 
degrees of cementation due to calcium carbonate, that is typical of karst cavity fills.

The siliceous component of the conglomerate and its yellowish red coloration (in the paraconglomerate matrix and in a reddish patina exhibited locally by pebbles and blocks) make it easy to distinguish it from the pale gray calcareous karst rock, leading us to consider that the type of sediment (Farrant, 2006) is allochthonous to the immediate area affected by karst processes.

Through our granulometric and morphometric analyses of the conglomerate sediments, we have identified specific facies of Cenozoic sediments present in La Balouta and verified the relationship between the presence of the paleokarst and the emplacement of gold deposits, because the karstic channels behave as excellent sediment traps (Farrant, 2006). The filling material appears to originate from sediments of the Las Médulas Formation, though it may also contain materials from the Santalla Formation and contemporaneous or subsequent deposits of this formation.

\section{Morphogenetic development of the La Balouta topography}

The morphogenesis of the La Balouta Valley cannot be understood without an examination of the regional morphostructures among which it is situated. The study area covers part of a depressed segment of the mountain belt that forms the southern margin of the Bierzo depression. The Bierzo is a small sedimentary basin located in the NW of the Iberian Peninsula that is surrounded by rugged mountains on all sides (The Cantabrian Mountain Range to the north and the Montes de León-Aquilanos-Caurel to the south). The drainage from the Bierzo flows towards the SW (Galicia).

The tectonic origin of the Bierzo depression appears to be uncontested, even when taking into account earlier interpretations claiming that an extensional tectonic depression framed by normal faults divided the mountainous blocks from the sedimentary basin (Sluiter \& Pannekoek, 1964; DelmaireBray, 1977; Hérail, 1981, 1984; Hérail \& Lucas, 1983). Similarly, we may also consider more recent interpretations that note a depression limited by significant thrust structures to the north and south that compressed the depression, locally pushed masses of the Paleozoic basement over Cenozoic sediments and covered them (Santanach, 1994; Martín-González, 2009; Martín-González \& Heredia, 2010, 2011). Despite deep downcutting of the Sil River, which crosses these thrusts, and despite retrogressive erosion that has led to its incision into Paleozoic structures, ancient remnants in the study area reflect morphologies within this topography that were present before sedimentation of Cenozoic conglomerates began. Thus, remnants have been identified of ancient Cenozoic erosive surfaces over resilient Paleozoic limestone (Hérail, 1981, 1984); calcareous paleo-topographies that lie beneath the Tertiary sedimentary succession (Martin-González \& Heredia, 2010); and paleo-valleys that pre-date the downcutting of the Sil River, as in the case of the Val de Injertos located on the other side of the Sil River valley (Redondo Vega et al., 1997).

The grain-size characteristics of the Cenozoic conglomerates and their specific positioning on the karstified limestone allowed us to reconstruct the morphogenetic evolution of the paleokarst, determine its relationship with the surrounding area and terrain morphology and propose a relative chronology of geomorphological events based on the following evolutionary model.

The La Balouta Valley initiated upon a subdued plain with little relief and only gentle slope changes, as would be expected for an ancient massif undergoing long-term development and breakdown due to erosion (Fig. 7a). Broad, planed surfaces predominated, some of which, at $860 \mathrm{~m}$, survive between La Balouta and the Sil Valley. Of the ancient Variscan structures that compose the topography, the massif of Ordovician limestone, which barely protruded upon the eastern side of the karst, developed in the presence of discontinuities and lines of weakness in the massif. Also favoring karst development on that edge was close contact between limestone and Paleozoic slate.

At the end of the Miocene (Fig. 7b) tectonic readjustments that affected the ancient massif triggered the establishment of a different set of uplifted and depressed blocks, generating a significant increase in the area's overall morphogenetic potential. At this point, extensive fans of conglomerate (Fig. 8)
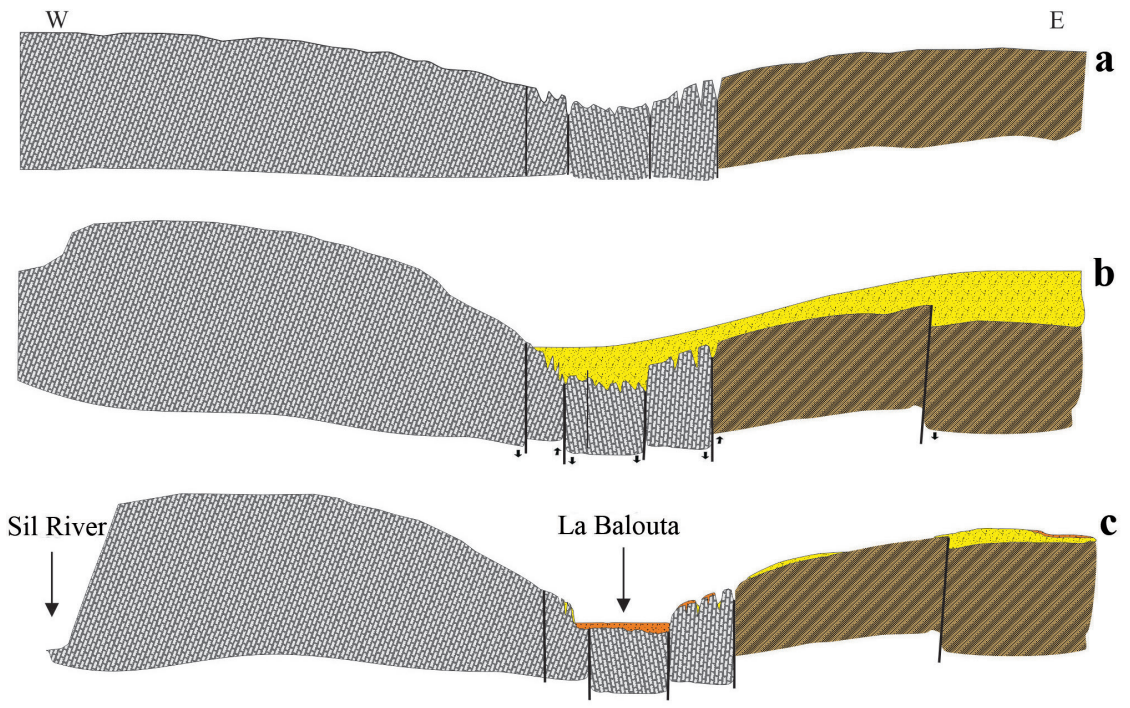

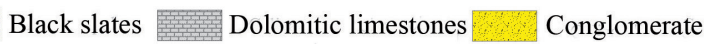

Mining waste materials

Fig. 7. a) The initial pre-Miocene topography was characterized by slight, uninterrupted elevation changes and slopes; a karst in the eastern portion of the massif that was formed from fractures and lines of weakness; and close contact with non-calcareous materials. b) At the end of the Miocene, tectonics moved blocks of the ancient massif differentially, causing greater elevation changes in the topography and leading to the accumulation of red conglomerates from the eastern and higher sections of the massif. The ancient karst was fossilized by red conglomerates containing gold. c) The current topography is approximately 2,000 years old and was first developed with the excavation of gold-bearing sediments that fossilized the paleokarst and resulted in its exhumation. Mining waste materials accumulate in the floor of the La Balouta Valley and at its opening towards the main valley. 


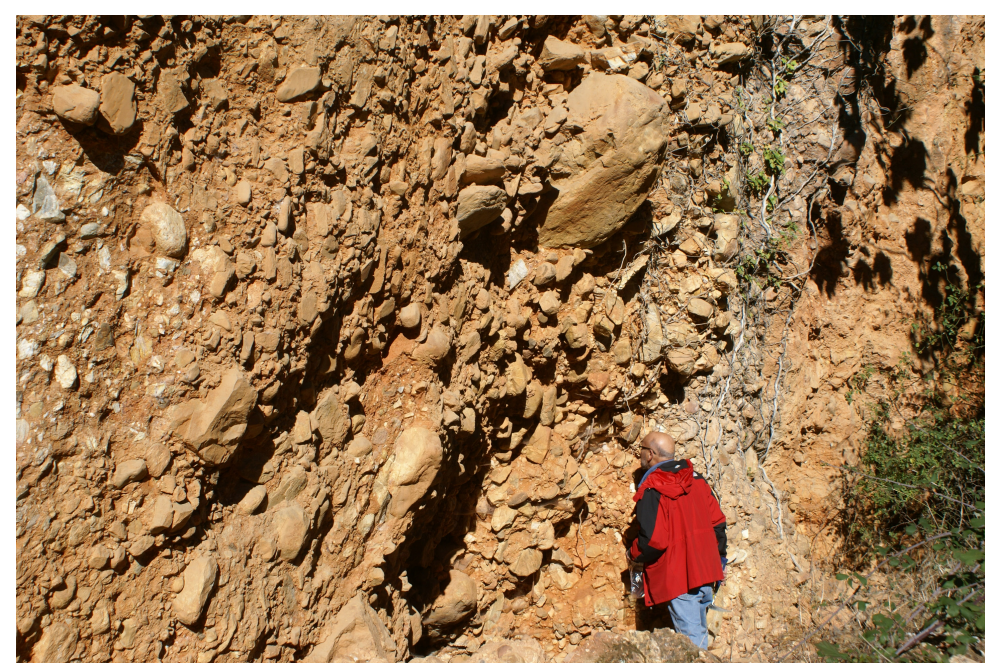

Fig. 8. Miocene conglomerates in La Balouta; the dominance of large rock fragments within a relatively minor enveloping matrix in some sections that characterize these geological formations is noticeable. Higher gold content in the area spurred Roman mining.

were deposited (Santalla Formation and Las Médulas Formation; Martín-González \& Heredia, 2010), sealing and burying the pre-existing karstic topography and forming a buried karst (Jennings, 1987; Bosák et al., 1989; Osborne, 2013). Processes related to red-facies sedimentation, especially at the start of this period, transported gold particles from the fan source areas (resulting from the destruction of paleo-soils covering the massif; Sánchez-Palencia et al., 1999), whit the gold remaining trapped (Filippov, 2006) in karstic channels filled with red Cenozoic sediment (Figs. 2 and 9).

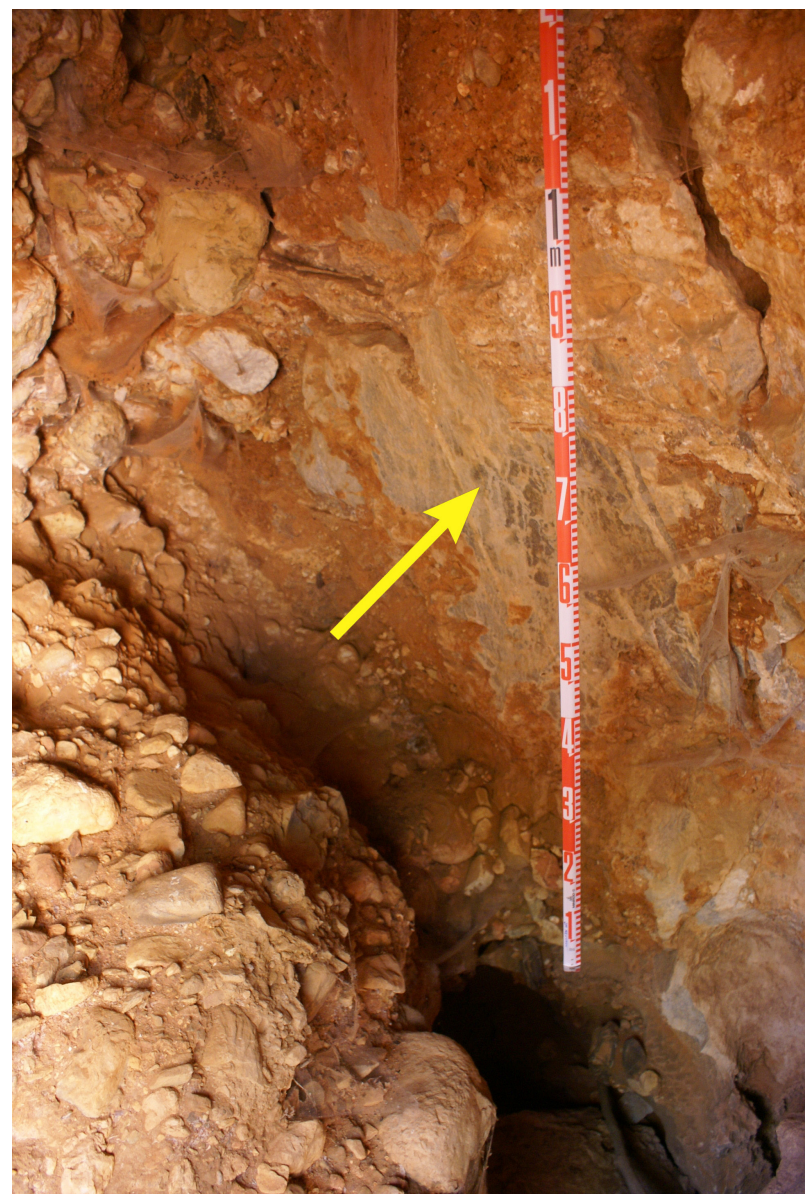

Fig. 9. A partially excavated subterranean channel; in the center, one can see limestone forming the wall of the channel that is devoid of conglomerate fill.
At the end of the Cenozoic, major block movements and deposition of conglomeratic sediment transported from the east ended, and the topography of the La Balouta Valley was modified as the Sil River cut down the massif. This incision of the Sil River fluvial network increased the network's morphogenetic potential and caused the partial removal of previously deposited conglomeratic sediments. In La Balouta this process was translated into sudden changes of gradients and flow dynamics, leading to the deposition of extensive spreads of calcareous colluvium. These were locally superimposed on the conglomerates and, reflecting the degree of cementation, they protected the conglomerates from disintegration throughout the valley's incision, though they were also excavated by the Romans (Fig. 10) to gain access to the underlying gold-bearing conglomerate.

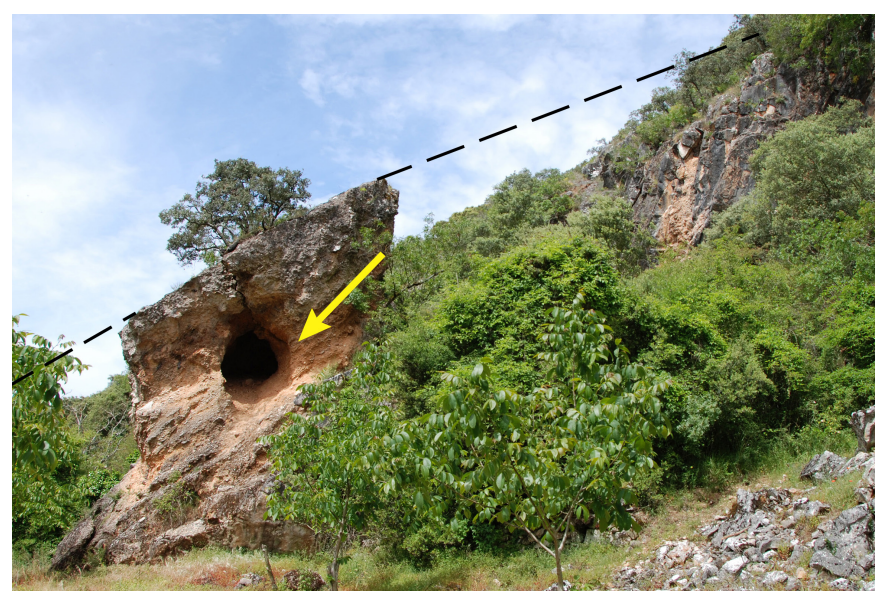

Fig. 10. The dotted line indicates an artefact of remains of the primitive topography of the La Balouta Valley, in which a mining gallery (arrow) is preserved in the cemented colluvium.

Finally, roughly 2,000 years ago, the floor of the La Balouta Valley (Fig. 7c) and karstic channels, fossilized by Cenozoic sediments, were partially excavated for gold, such the exhumation of the paleokarst occurred (Fig. 11). Waste materials generated from mining activities (and other materials generated from major mining operations in Las Médulas) were dumped throughout the valley and at one stage were dumped

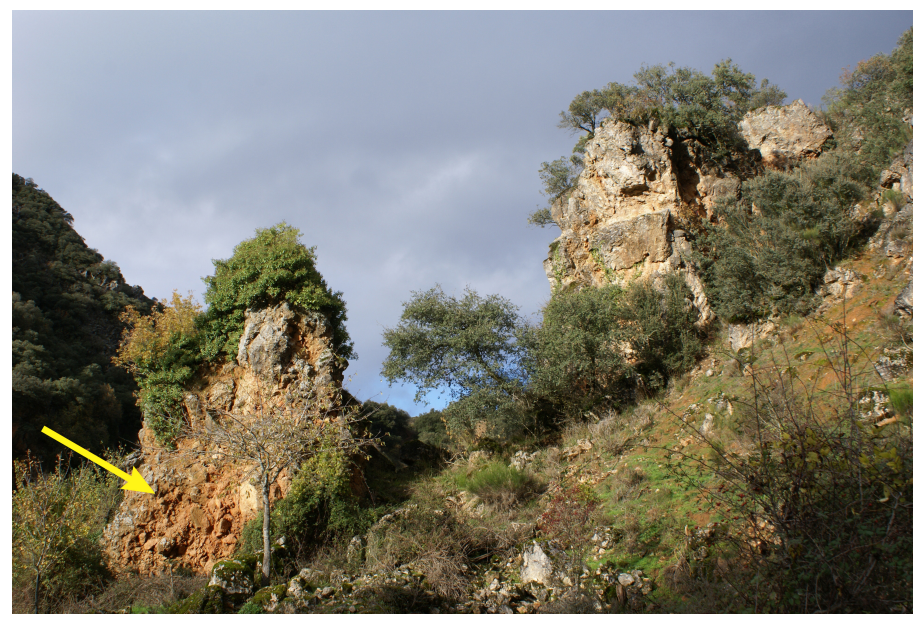

Fig. 11. Residual topography of the paleokarst exhumed by mining activities; the mogote to the left retains well-attached remnants of the reddish conglomerate (arrow). 
beyond the valley's narrowest point, forming a giant debris cone more than $2 \mathrm{~km}$ in length that nearly reaches the town of Salas de la Ribera in the main valley of the Sil River. Evidence of valley excavation includes not only remains of the original topography noted above (Fig. 10) and excavated subterranean channels but also a vertical cliff, approximately $10 \mathrm{~m}$ high, which is clearly visible from certain sections of the right side of the valley (Fig. 12) as a break in the net slope of the calcareous valley wall.

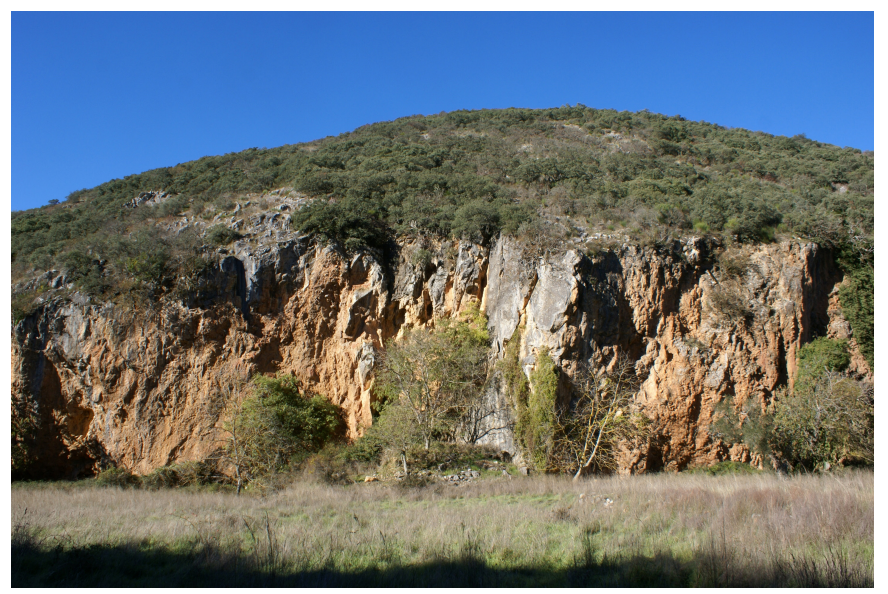

Fig. 12. Vertical face of over $10 \mathrm{~m}$ in height in Paleozoic limestone exhumed via mining excavation. This likely aligns with an ancient NE-SW guiding fault in the massif.

\section{DISCUSSION}

\section{Karstic evidence in La Balouta}

Limestone rocks in vertical and horizontal subterranean channels within the La Balouta Valley includes abundant forms of exogenous (dissolution channels and sinkholes, Stevanovic, 2015) and endogenous karstic material. These are highly evolved shapes, as indicated by an absence of speleothems in the majority of accessible subterranean channels and by evident signs of their decalcification. In addition, shapes indicate complete fossilization processes (especially in the lower parts of the current La Balouta Valley) by red conglomerates similar to those of deposits near Las Médulas. Fossilization processes influenced the karstic paleo-topography by contributing to its filling and preservation; this confinement preserved the sediments by stabilizing them (Farrant, 2006), as in other similar topographies that remain in sub-aerial condition such as paleokarst channels and galleries.

Many of these karstic features are difficult to identify, because they are hidden by dense Mediterranean vegetation. Processes of plant colonization have been rapid since the area was depopulated decades ago, as indicated by aerial images of the area from more than sixty years ago that show signs of marginal and dispersed agricultural activity.

Despite the presence of this vegetation, it is still possible to observe some forms. Whereas some are fully exposed, others are only partially exposed, though in all cases they reveal conglomerate remains. At some localities within ancient caves and subterranean channels much of an original conglomeratic fill has been removed by mining, leaving only a few pebbles or blocks of quartzite and sandstone adhering to the walls and roof of caves. No indications of natural paleokarst excavation have been observed: per-ascensum speleogenesis (Ford, 1995) hypogene speleogenesis (Osborne, 2013), eustatic sea level, paragenesis, highdensity speleogenesis (Ford, 1995), glaciation, large scale meteoric speleogenesis (Osborne, 2002). Thus, anthropogenic activities must have been responsible for the exhumation of the La Balouta karst.

At a small scale, speleothems are visible from many areas of the valley that are now sub-aerial but whose formation was originally subterranean. Locally, alternating speleothems and conglomeratic sediment beds indicate partial processes of paleokarst filling over several phases, as shown by the presence of thin interstratified flowstones covering the allochthonous sediment (Gillieson, 2006). In other cases, crystalline aggregates are preserved (Self $\&$ Hill, 2003) at various locations within the exhumed paleokarst, with subaquatic forms such as micro-gours (rimstone dams) and coralloid speleothems (coralloids) (Hill $\&$ Forti, 1997). These forms appear to be sealed by allochthonous conglomerates forming a sequence that denotes that concretion formations at the center of the micro-lake were interrupted by two allochthonous pebble and gravel sedimentation events (Fig. 13).

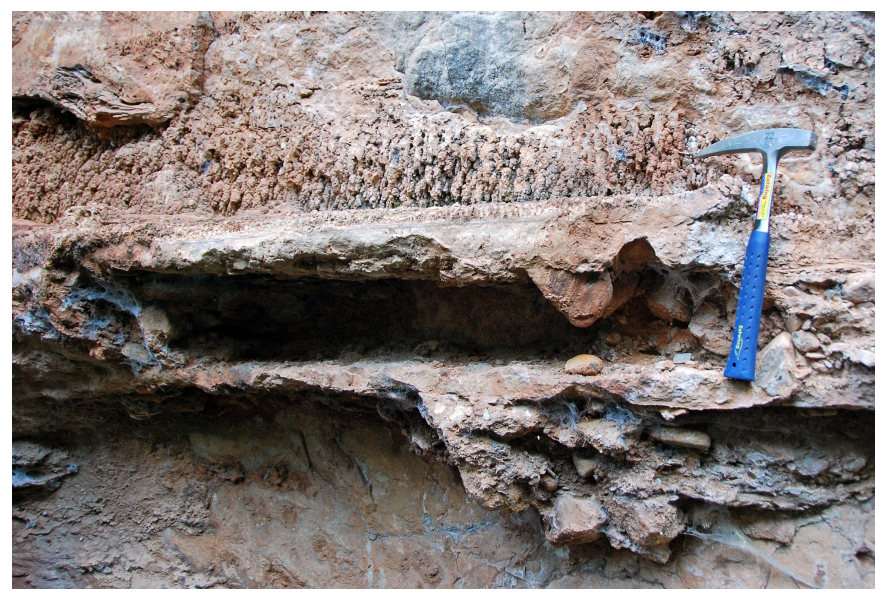

Fig. 13. Two levels of speleothems corresponding to ancient microgours, with coralloid formations in the top portion; these were fossilized by allochthonous conglomerates and were subsequently excavated by Roman miners; they are located in the lowest section of the La Balouta Gorge.

\section{Evidence of mining activity in La Balouta}

Some features of the present La Balouta Valley appear to be connected to mining operations in Las Médulas because, to the north, the valley opens toward the Lago Somido area, and this section of the valley covers a vast zone of accumulated mining waste materials (murias) composed of sandstone and quartzite pebbles and blocks. To the east, three small valleys (one occupied by a lake) excavated in the conglomerates connect without interruption to the main deposits of Las Médulas. Its relationship to major mining operations has already been explored by several authors (Sánchez-Palencia et al., 1999; Pérez García \& Sánchez-Palencia, 2000), though these authors considered it as a point of exit for waste materials from the main mine and not as an additional mining area. 
On this issue, the La Palombeira Gallery, about $190 \mathrm{~m}$ long, was excavated for slate in the southern section of the study area. Some authors believe that this area worked as a bypass for the removal of Roman waste materials from the mining operation at Las Médulas and to circumvent the narrowest part of the La Balouta Valley (Sánchez-Palencia et al., 1999; Pérez García \& Sánchez-Palencia, 2000). The passage south of the La Palombeira Gallery/Tunnel is still accessible and coincides with the summit of a giant debris cone formed from the gold-mining debris (Fig. 4). Currently, the gallery is positioned approximately $20 \mathrm{~m}$ above the floor of the La Balouta Valley, from which it appears clearly disconnected. In contrast, the section at the south entrance of the tunnel (Fig. 14) suggest a deepening of the tunnel that may be related to the deepening mining excavations in the La Balouta karst located immediately to the north. This serves as additional evidence of mining activity in the karst.

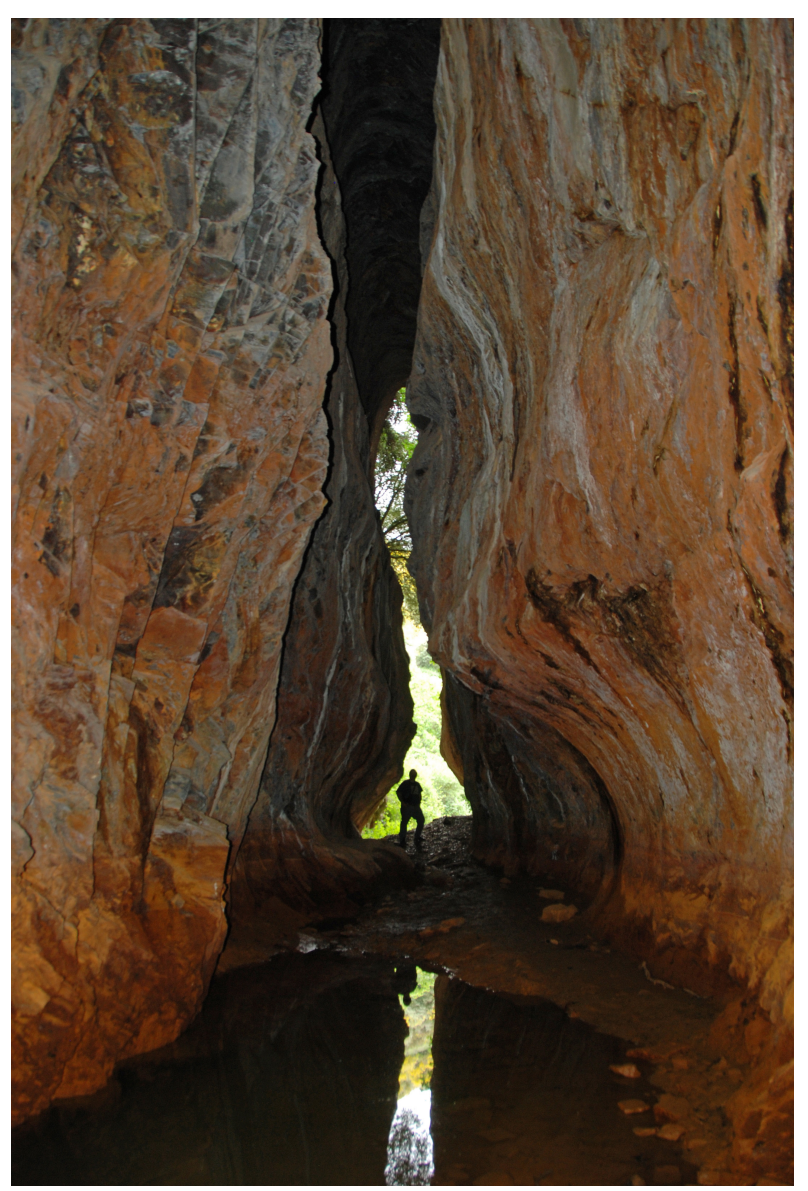

Fig. 14. Gallery of La Palombeira located in the southern part of the study area. According to some researchers, it functioned as a bypass that carried Roman mining waste materials from Las Médulas, bypassing the narrowest section of the La Balouta Valley.

We believe that in addition to serving as a dumping area for waste materials, La Balouta functioned as an area for gold extraction, as indicated by the presence of several karstic channels with clear signs of excavation (Fig. 9). The presence of two small gold fragments (Fig. 5) in one of the samples gathered from conglomerates of the lower section of a semi-excavated channel serves as additional evidence of the mining utility that this valley probably offered to Roman miners.
Moreover, at several points in the valley, isolated remains of the paleokarst (Figs. 3 and 11) were found in the middle of the hillside. Rectilinear incisions (Fig. 12) dug into the limestone (that still retain remnants of the conglomerate) were also found. Both features have no relation to the present morphology of the valley. We believe that these disconnected features of the original valley topography also indicate the existence of ancient mining activities.

Was this a paleokarst excavated by Roman miners to extract gold from the conglomerate that previously fossilized it? If this is the case, this paleokarst would constitute a unique site in northwestern Spain, where hundreds of gold mines from the Roman era are found (Keay, 1988), as Camporredondo and La Balouta are the only found sites composed of karstic paleotopographies covered by gold-bearing sediment.

As the La Balouta Valley essentially has no head and underwent mining operations in Las Médulas, it appears plausible that its excavation resulted from anthropogenic activities rather than natural processes.

In addition, the channel/gallery excavated in the above-described colluvium (Fig. 10) reveals characteristics of the valley's topography present before the Roman era activities began, and also deep incisions on the left side of the valley (Fig. 15) that open towards an area of waste material accumulation.

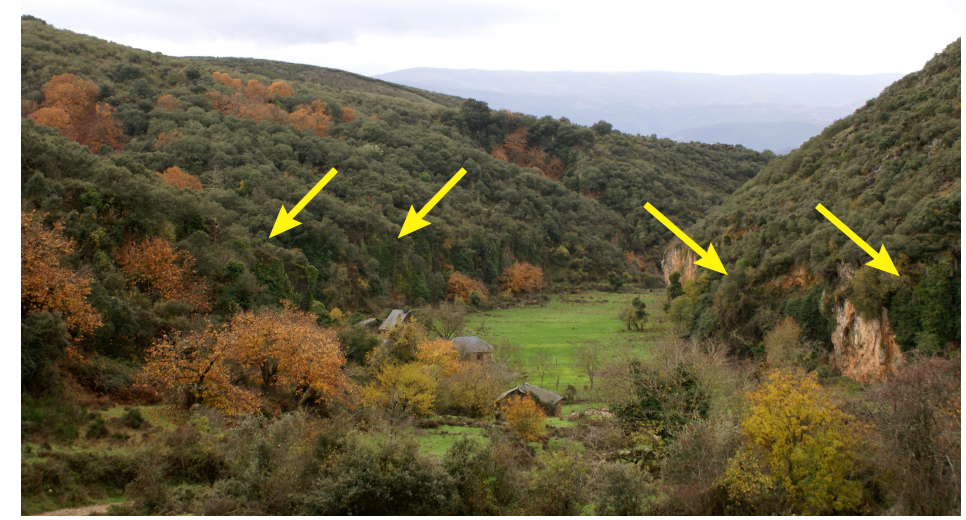

Fig. 15. La Balouta, the arrows denote areas excavated due to gold mining.

All of these data on the valley support its definition as a heritage site, and especially if we consider the presence of fossilized karstic formations and their use for historical mining. Discounting some natural processes that might have reactivated the karst or led to its excavation, the partially exhumed karstic formations must have been revealed by Roman mining activities.

\section{CONCLUSION}

Landscape transformations resulting from mining resource extraction are rare when compared to changes caused by other human activities such as agricultural or urban activities (Hooke et al., 2012). Nonetheless, these are permanent and irreversible changes that have left deep marks on the landscape. UNESCO deemed Las Médulas a cultural heritage site in 1997 
because of the presence of archaeological and mining remains rather than as a cultural landscape due to negative connotations associated with considering land formations resulting from destructive mining processes within culturally valuable landscapes (Bandarin, 2007).

Along with other authors (Pérez García \& SánchezPalencia, 2000), we do consider the site a cultural landscape, because humans acted as primary shapers of the landscape through mining, drastically transforming original landscapes and uncovering evidence of morphogenetic processes such as those of the La Balouta paleokarst, which had remained hidden for millions of years.

In La Balouta, limestone karstification created very favorable conditions for collecting (Filippov, 2006) gold traces transported within red Miocene sediments. As such, gold deposits were mined by the Romans, leading to the exhumation of ancient karstic landforms, which had until then been covered with sediments. The relationship between karst exhumation and Roman gold mining of Las Médulas deposits has already been described in a previous study on this site (Redondo Vega et al., 2011).

The spatial convergence of karstified limestone and Roman gold mining helped to establish three distinct moments in the evolution of this topography: the karstification of an ancient Paleozoic massif, the burying of resulting karstification landforms by Cenozoic sediments, and the exhumation of the paleokarst via Roman gold mining.

Gold mining at Las Médulas was not exclusively linked to the areas examined, but extended toward more distant areas of the Cenozoic sedimentary complex. Gold-bearing sediments covered the Paleozoic basement, which in the La Balouta Valley is composed of a paleokarst as a previous topographic landscape. The paleokarst is located along the edge of a calcareous block that still includes channels that have been semifossilized by conglomeratic Cenozoic sediments.

This form of mining involving the exhumation of karstic paleo-landfoms (which is rarely found in global cases of historical mining) is a novel finding in the northwestern region of the Iberian Peninsula. Although karstified areas and paleokarsts are relatively common, they very seldom coincide with a karstified basement fossilized by gold-bearing sediments. Such cases are rare, as they reflect a convergence of natural and anthropogenic processes in current configurations of the topography.

Fossilized karst exhumation in La Balouta (Las Médulas) resulted from Roman mining activities and serves as an additional case of intensive and extensive gold mining activities executed by Romans in northwestern Spain. Our findings show that such mining activities were also systematic and comprehensive in nature.

\section{ACKNOWLEDGMENTS}

We thank the technical personnel who helped develop content areas of the Casa del Parque del Monumento Natural de las Médulas, and we thank
Fundación Patrimonio Natural de Castilla y León, and Marta Ferrero in particular for facilitating access to the natural area. We thank the editor and three anonymous reviewers for their constructive comments, which helped us to improve the manuscript.

\section{REFERENCES}

Abril Hurtado J., Pliego Dones D. \& Rubio Navas J., 1978 - Información Complementaria. Fotografias. Mapa Geológico de España, E. 1: 50.000, no 191, Silván. Geotehic SA, Madrid, Spain; fotografia $n^{\circ}$ AH 536a y $n^{\circ}$ AH 536b. Available at: http:/ /info.igme.es/sidimagenes / magna/20191/fotografias $\% 201 /$ fotografias $\% 201 . p d f$

Abril Hurtado J., Pliego Dones D. \& Rubio Navas J., 1982 - Mapa Geológico de España, E. 1: 50.000, $n^{\circ} 191$, Silván. IGME, Madrid, 56 p.

Available at: http://info.igme.es/cartografia/datos/ magna50/jpg/d1_jpg/Editado_MAGNA50_191.jpg

Bandarin F. (Dir), 2007 - World Heritage, Challenges for the Millennium. UNESCO, World Heritage Centre, Paris, $200 \mathrm{p}$.

Bird D.G., 1984 - Pliny and the gold mines of north-west Iberia. In: Blagg, T., Jones R. \& Keay S. (Eds.), Papers in Iberian archeology. BAR International Series, Oxford, 193: 341-363.

Bosák P., 1989 - Mineral deposits connected with karst. In: Bosák P., Ford D., Glazek J., \& Horacek I. (Eds.), Paleokarst: a systematic and regional review. Elsevier, Amsterdam, p. 365-375.

Bosák P., Ford D.C. \& Glazek J., 1989 - Terminology. In Bosák P., Ford D.C., Glazek J., \& Horacek I. (Eds.), Paleokarst: a systematic and regional review. Elsevier, Amsterdam, p. 25-35.

http://dx.doi.org/10.1016/B978-0-444-98874-4.50010-0

Delmaire-Bray M.M., 1977 - Les grandes étapes d'individualisation du basin du Bierzo (León, Espagne) à partir du néogenè. Méditerranée, 1: 19-34. http://dx.doi.org/10.3406/medit.1977.1707

Domergue C., 1987 - Catalogue des mines et des fonderies antiques de la Péninsule Ibérique. Publications de la Casa de Velásquez, Madrid, TI, 344 p.

Ejército del Aire. Centro Cartográfico y Fotográfico, 1956 - Foto Aérea, Vuelo Americano, no 20370-20371.

Farrant A., 2006 - Paleoenvironment: clastic cave sediments. In: Gunn J. (Ed.), Encyclopedia of caves and karst science. Fitzroy Dearborn, New York, p. 1180-1185.

Fernández-Martínez E., Fuertes Gutiérrez I., Alonso Herrero E., Redondo Vega J.M ${ }^{\mathrm{a}}$., Cortizo Álvarez J., Gómez Villar A., Santos González J., Herrero Hernández A. \& González Gutiérrez R.B., 2009 Inventario de Lugares de Interés Geológico (LIG) de la provincia de Palencia. DVD. Fundación Patrimonio Natural, Valladolid, 307 p.

Fernández Ochoa C. \& Morillo Cerdán A., 2013 Poblamiento y explotación de los recursos mineros en el Cantábrico. In: Zarzalejos Prieto M., Hevia Gómez P. \& Mansilla Plaza L. (Eds.), Paisajes mineros antiguos de la Península Ibérica. Investigaciones recientes y nuevas lineas de trabajo. Madrid, UNED, p. 171-184.

Filippov A.G., 2006 - Mineral deposits in karst. In: Gunn J. (Ed.), Encyclopedia of caves and karst science. Fitzroy Dearborn, New York, p. 1098-1102.

Ford D.C., 1995 - Paleokarst as a target for modern karstification. Carbonates and Evaporites, 10 (2): 138-147. http://dx.doi.org/10.1007/BF03175399

Gil y Carrasco E., 1985 - Bosquejo de un viaje a una provincia del interior (1843). Colección Breviarios de la Calle del Pez, no 10, Diputación Provincial de León, León, $135 \mathrm{p}$. 
Gillieson D., 2006 - Sediments: autochthonous clastic. In: Gunn J. (Ed.), Encyclopedia of caves and karst science. Fitzroy Dearborn, New York, p. 1350-1353.

Hérail G., 1981 - Le Bierzo: géomorphogénèse finitertiaire d'un bassin intramontagneux (Espagne). Revue Géographique des Pyrénées et Sud-Ouest, 52 (2): 117-132.

Hérail G., 1984 - Géomorphologie et gîtologie de l’or détritique. Piémonds et bassins intramontagneux du Nord-Ouest de l'Espagne. CNRS, Paris, 456 p.

Hérail G. \& Lucas C., 1983 - Dynamique comparée de deux bassins continentaux tarditectectoniques: le bassin tertiaire du Bierzo (León, Espagne) et le bassin permien d'Aure (France). Revue de Géologie Dynamique et de Géographie Physique, 24 (2): 117-128.

Hill C.A. \& Forti P., 1997 - Cave minerals of the world ( $2^{\text {nd }}$ ed.). National Speleological Society, Alabama, 463 p.

Hooke R., Martín-Duque J.F. \& Pedraza J., 2012 - Land transformation by humans: a review. GSA Today, 22 (12): 4-10. http://dx.doi.org/10.1130/GSAT151A.1

IGN (Instituto Geográfico Nacional), 2008 - Ortofotografia digital. Available at: http://www2.ign.es/iberpix/ visoriberpix/visorign. $h$ tml? $\mathrm{x}=682151.25138 \mathrm{y}=$ 4702383.9766\&zone $=29 \& \mathrm{r}=474 \& v i s i b l e=\mathrm{PNOA}$

Jennings J.N., 1987 - Karst geomorphology (2 $2^{\text {nd }}$ ed.). Basil Blackwell, Oxford, 293 p.

Jennings J.N., 2003 - Karst. An introduction to systematic geomorphology, Vol. 7. The MIT Press, London, 272 p.

Keay S.J., 1988 - Roman Spain (Exploring the Roman World). University of California Press/British Museum, London, $240 \mathrm{p}$.

Martín-González F., 2009 - Cenozoic tectonic activity in a Variscan basement: Evidence from geomorphological markers and structural mapping (NW Iberian Massif). Geomorphology, 107: 210-225.

http://dx.doi.org/10.1016/j.geomorph.2008.12.008

Martín-González F. \& Heredia N., 2010 - Estructuras alpinas en la terminación occidental de los relieves del Orógeno Pirenaico y su relación con la Sedimentación terciaria (Macizo Ibérico, NO Peninsular). XXII Reunión de la Comisión de Tectónica de la Sociedad Geológica de Ponferrada Guía de Campo. Universidad Rey Juan Carlos-IGME, Madrid, p. 1-24.

Martín-González F. \& Heredia N., 2011 - Complex tectonic and tectonostratigraphic evolution of an Alpine foreland basin: The western Duero Basin and the related Tertiary depressions of the NW Iberian Peninsula. Tectonophysics, 502: 75-89. http://dx.doi.org/10.1016/j.geomorph.2008.12.008

Miras Ruiz A. \& Galán Huertos E., 1992 - Las mineralizaciones de barita del Cerro del Hierro (Sevilla). Características mineralógicas y geoquimicas. Estudios Geológicos, 48: 91-99. http://dx.doi.org/10.3989/egeol.92483-4373

Osborne R.A.L., 2002 - Paleokarst: cessation and rebirth? In: Gabrovsek F. (Ed.) - Evolution of karst: from prekarst to cessation. Karst Research Institute, Ljubljana, p. 97-115.
Osborne R.A.L., 2013 - Preservation and burial of ancient karst. In: Shroder J. \& Frumkin A. (Eds.) - Treatise on geomorphology. Academic Press, vol. 6, Karst Geomorphology, San Diego, p. 95-103.

http://dx.doi.org/10.1016/B978-0-12-374739-6.00132-9

Pérez García L.C. \& Sánchez-Palencia F.J., 2000 El yacimiento aurifero de Las Médulas: situación y geología. In: Sánchez-Palencia F.J. (Ed.) - Las Médulas (León). Un paisaje cultural en la Asturia Augustana. Instituto Leonés de Cultura, León, p. 139-188.

Redondo Vega J.Mª., Gómez Villar A. \& González Gutiérrez R.B., 1997 - Morfología y estructura en el valle del río Selmo (Sierra del Caurel, León). Polígonos, 7: 97-122. Available at: http://revpubli.unileon.es/ ojs/index.php/poligonos/article/view/1060/885

Redondo Vega J.Ma ., Gómez Villar A. \& González Gutiérrez R.B., 2004 - Patrimonio geomorfológico de los espacios naturales protegidos de la provincia de León. Junta de Castilla y León (unpublished report), 120 p.

Redondo Vega J.M ${ }^{\mathrm{a}}$., Fernández Martínez E., Fuertes Gutiérrez I. \& Alonso Herrero E., 2010 - El karst exhumado de Los Peñucos (Camporredondo de Alba, Palencia, España): un ejemplo de patrimonio geológico y minero. Cuadernos del Museo Geominero, 12: 151-171. Available at: https://www.researchgate. net/publication/259048485 El karst exhumado de Los_Peucos_\%28Camporredondo_de_Alba_Palencia Espaa\%29 un ejemplo de patrimonio geolgico y minero Redondo Vega J.M ${ }^{\mathrm{a}}$., Alonso Herrero E. \& Santos González J., 2011 - El karst exhumado de La Balouta: un ejemplo de patrimonio geológico y minero derivado de las explotaciones auriferas romanas. In: FernándezMartínez E. \& Castaño de Luis R. (Eds.) - Avances y retos en la conservación del patrimonio geológico en España. Actas de la IX Reunión Nacional de la Comisión de Patrimonio Geológico, León, p. 226-230.

Salomon J.N., 2000 - Précis de karstologie. Presses Universitaires de Bordeaux, Bordeaux, 250 p.

Sánchez-Palencia F.J., Fernández-Posse M.D., Fernández Manzano J. \& Orejas A., 1999 - La zona arqueológica de Las Médulas. Instituto de Estudios Bercianos, Ponferrada, $147 \mathrm{p}$.

Santanach P., 1994 - Las cuencas terciarias gallegas en la terminación occidental de los relieves pirenaicos. Cuadernos del laboratorio Xeolóxico de Laxe, 19: 57-71.

Self C.A. \& Hill C.A., 2003 - How speleothems grow: An introduction to the ontogeny of cave minerals. Journal of Cave and Karst Studies, 65 (2): 130-151.

Sluiter W.J. \& Pannekoek A.J., 1964 - El Bierzo, étude sédimentologique et géomorphologique d'un bassin intramontagneux dans le NW de l'Espagne. Leidse Geologische Mededelingen, 30: 141-181.

Stevanovic Z. (Ed.), 2015 - Karst aquifers-characterization and engineering. Springer International Publishing, 692 p. http://dx.doi.org/10.1007/978-3-319-12850-4

UNESCO, 2015 - World Heritage Centre. Resources. World Heritage List: Las Médulas. Available at: http://whc.unesco.org/en/list/803. 